\title{
ANALYSIS OF THE EFFECTS OF QUALITY WORK OF LIFE FACTORS ON EMPLOYEE MOTIVATION REGIONAL OFFICE OF UNIVERSITAS TERBUKA AT PANGKALPINANG, INDONESIA
}

\author{
Yusuf 1*, Adrian Sutawijaya ${ }^{2}$ \\ ${ }^{1,2}$ Universitas Terbuka Pangkalpinang, Pangkalpinang, Indonesia
}

\begin{abstract}
The purpose of this research is to know the description of Quality of Work Life and Employee Motivation in UPBJJ-UT Pangkalpinang, and its influence is partially and simultaneously so that it can get information to increase motivation which will improve the quality of organizational performance. The research method used is descriptive quantitative approach with cross sectional design. The sample in this study amounted to 30 samples. The type of data used is the primary data. Data analysis technique using multiple linear regression test. The results showed that (1) The overall variables had a high average value that is in the category of 3.41-4.20 and the variable of pride to the institution had the highest average value of $4.21 \%$. Thus the majority of respondents feel proud of the institution while working at UPBJJUT Pangkalpinang. In general, there are seven variables that have positive and significant influence and four variables that have positive but not significant influence. Variables that have positive and significant impacts are available facilities, workplace safety, employee engagement, communication, security, a sense of pride in institutions and work restructuring. While the variables that have positive but not significant are balanced compensation, career development, problem solving and work environment (3) Simultaneously the Quality of Work Life variable has a positive and significant influence on work motivation. This means that any increase or decrease in Quality of Work Life together will give a significant influence on employee motivation in UPBJJ-UT Pangkalpinang.
\end{abstract}

Keywords: Employee Motivation, Quality of Work Life, Work Motivation

\section{INTRODUCTION}

Human resources is the main asset of the organization and has a strategic role within the organization as a thinker, planner and control of organizational activities. To achieve organizational goals, one of the things that managers need to do is to provide motivation that can arouse passion and morale, improve morale and satisfaction, increase work productivity, maintain loyalty and stability of employees and improve discipline and reduce employee absenteeism (Hasibuan, 2007).

According to Cascio (2003), companies should create an atmosphere of work where employees feel their involvement in the company, their participation in decision making, a sense of security for the work environment, good communication between employees and with superiors, a growing career and a sense of pride in work. Working atmosphere like this will lead to Quality

* Corresponding author. Email address: yusuf_se@ecampus.ut.ac.id 
of Work Life (QWL) is good. Good Quality of Work Life can generate work motivation and worker performance in an effort to achieve company goals better. Implementation of quality of work life will affect employee work motivation and can improve work productivity of employees. However, when a company is unable to implement a good quality of work life, it will find it difficult to generate employee morale and maintain employee loyalty to the company. Therefore it is necessary to discuss the components of Quality of Work Life on employee motivation in UPBJJ-UT Pangkalpinang. Thus, the results obtained become information for increased motivation that will ultimately improve the quality of organizational performance. Therefore, the researcher wanted the research on "Analysis of the Effect of Quality of Work Life Factors on Employee Motivation at UPBJJ-UT Pangkalpinang".

\section{LITERATURE STUDY}

Saputri (2015), entitled Relation of quality of work life component with non-medical motivation in public hospital of rebo market area in 2015 states that most non medical employees have high work motivation. All QWL components, available facilities, workplace safety, employee engagement, balanced compensation, communications, career development, problem solving, job security, institutional pride, work restructuring and work environment are well assessed by employees non medical at RSUD Pasar Rebo.

Samtica (2011), entitled Relation of Quality of Work Life with work motivation of nurse executor at RS Haji Jakarta in 2011 stated that the motivation of Nurse Nur Haji Hospital Jakarta in 2011 stated high enough. There is a significant relationship between the components of quality work of life which consist of available workplace safety facilities, employee involvement, balanced compensation, career development communication, problem solving, job security and a sense of pride in institution with motivation to work nurse of RS Haji Jakarta in 2011.

Dewi (2006), in his research study entitled Analysis of the Effect of Quality of Work Life on Employee Achievement Motivation (Case Study Head Office PT Pos Indonesia (Persero) obtained the result that the motivation of achievement of employees at PT Pos Indonesia (Persero) tend to good and generally quality the work life of PT Pos Indonesia (Persero) employees tends to be good.The result of partial influence test shows that only improvement factor of work environment able to explain dependent variable of achievement motivation if other independent variable is controlled.

\section{RESEARCH METHODOLOGY}

\section{Types and Data Sources}

The data used in this research is quantitative data with cross sectional design. Quantitative data with data collection related to dependent or dependent variable (employee motivation UPBJJ-UT Pangkalpinang) and independent variable (quality of work life) observed at the same time. The data source comes from primary data and secondary data. Primary data is obtained directly through observation activities on the activities undertaken by employees during the work time and the results of interview activities.

\section{Population and Sample Research}

The research population is Head of UPBJJ-UT Pangkalpinang, academic and student administration unit at Administration Unit (TU) and Registration 
and Exam Unit (RU) and Learning and Service Learning Unit (BBLBA) UPBJJ-UT Pangkalpinang with 30 respondents . The sample in this study is all members of the population in the three units. The use of 30 respondents is because the population is so small that based on the table to determine the size based on the specific population developed by Krejcie and Morgan (1970) The population is below $\mathrm{N}=25$, then the number of population $(\mathrm{N})=$ number of sample (S). (Sekaran, 2011).

The sampling method of each unit is done by sampling saturation or sample determination by taking all the population amount (Sugiyono, 2004).

\section{Framework for Operational Thinking}

Based on the description of the Quality of Work Life component proposed by Nawawi (2001) and Cascio (2003), the researcher used eleven (11) Quality of Work Life components consisting of nine (9) Quality of Work Life components according to Cascio, available facilities, workplace safety, employee engagement, balanced compensation, communication, career development, problem solving, job security, and institutional pride. While two (2) components of Quality of Work Life according to Nawawi, namely the restructuring of work and work environment. Where eleven (11) components of Quality of Work Life is independent variable, while the dependent variable is work motivation. The research concept framework used by researchers can be seen in Figure 1 below:

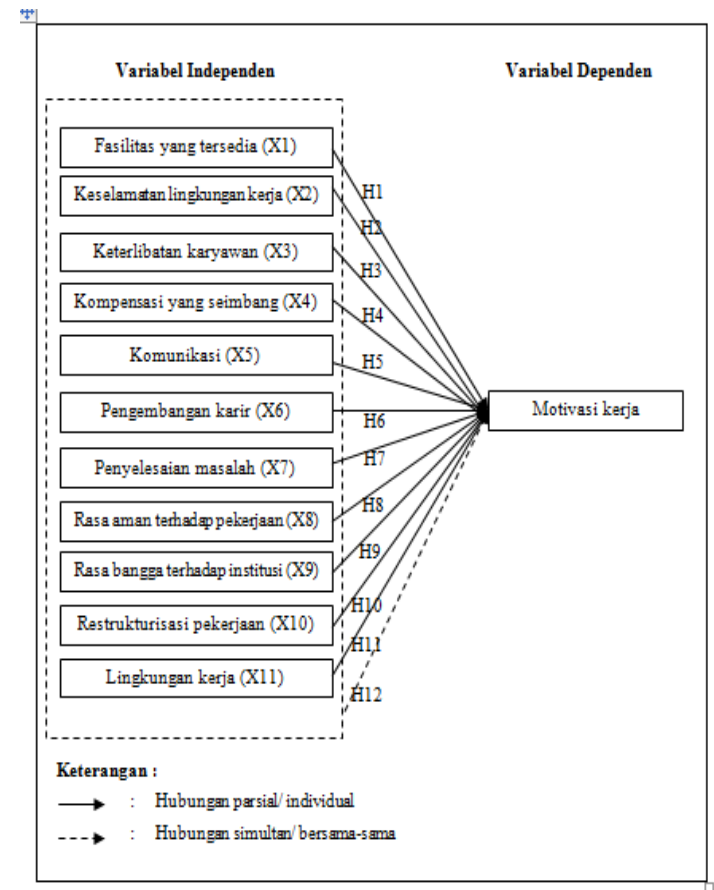

Figure 1 Concept Research Framework

\section{RESULTS}

\section{Descriptive Statistics Analysis}

Scale categories according Sugiono (2013) above analysis results note that the overall variables in this study has a high average value that is in the category of 3.41-4.20. and variable pride to the institution has a very high average value of $4.21 \%$. Thus the majority of respondents feel proud of the institution while 
working at UPBJJ-UT Pangkalpinang. And in general the quality of work life and work motivation factors in UPBJJ-UT Pangkalpinang are considered high.

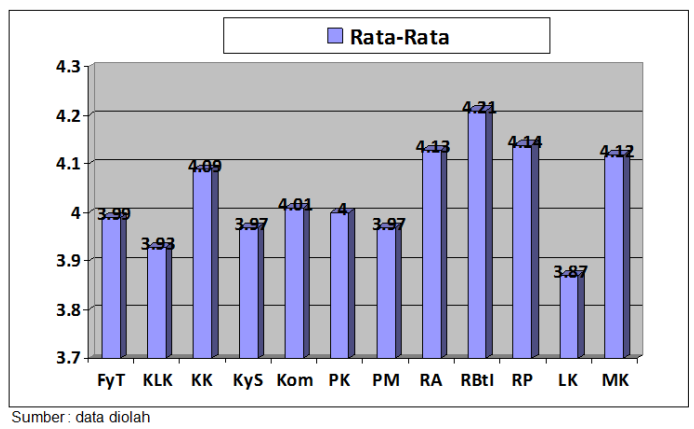

Figure 2 Average Value of Descriptive Test Result

\section{Test Validity and Reliability}

Validity test is used to measure the validity or validity of a questionnaire. The minimum requirement to be considered a valid instrument item is the value of its validity index (Pearson Correlation value) has $r$ hitung $>r$ tabel ie 0.374. The results of validity test in this study all have a value of rhitung larger than rtabel so that the whole of the instrument instrument is said to be valid.

Table 1 Reliability Test Results

\begin{tabular}{lcc}
\hline \multicolumn{1}{c}{ Variabel } & $\begin{array}{c}\text { Chronchbach } \\
\text { Alpha }\end{array}$ & Keterangan \\
\hline Fasilitas yang Tersedia & 0,764 & Reliabel \\
Keselamatan Lingkungan Kerja & 0,763 & Reliabel \\
Keterlibatan Karyawan & 0,743 & Reliabel \\
Kompensasi yang Seimbang & 0,714 & Reliabel \\
Komunikasi & 0,745 & Reliabel \\
Pengembangan Karir & 0,713 & Reliabel \\
Penyelesaian Masalah & 0,709 & Reliabel \\
Rasa Aman & 0,812 & Reliabel \\
Rasa Bangga terhadap Institusi & 0,655 & Reliabel \\
Restrukturisasi Pekerjaan & 0,795 & Reliabel \\
Lingkungan Kerja & 0,836 & Reliabel \\
Motivasi Kerja & 0,878 & Reliabel \\
\hline Sumber : data diolah & &
\end{tabular}

Based on Table 1. where the reliability test results indicate that all variables have a large enough Chronchbach Alpha coefficient that is above 0.60 so it can be said all the measuring concepts of each variable of the questionnaire is reliable which means that the questionnaire used in this study is a questionnaire that is reliable.

\section{Classic assumption test Normality test}

Normal plot chart view presented above can be concluded that histogram graph gives normal distribution pattern. While on a normal graph the plot looks spots spread around the diagonal line, as well as its spread following the direction of the diagonal line. These two graphs show that the regression model is worth using because it satisfies the assumption of normality. 

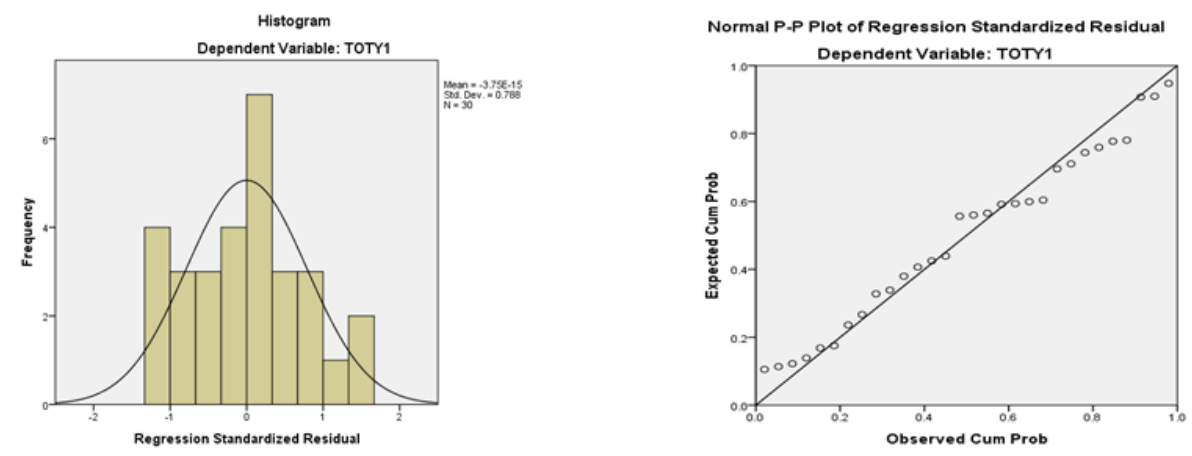

Sumber : data diolah

Figure 3 Normality Test Results

\section{Heteroscedasticity Test}

Scatterplot graphic results presented above show the spreading points randomly and spread over and below the number 0 on the y-axis, and does not have a clear pattern or form a pattern. So it can be concluded that there is no problem of heteroskedastisitas on regression model.

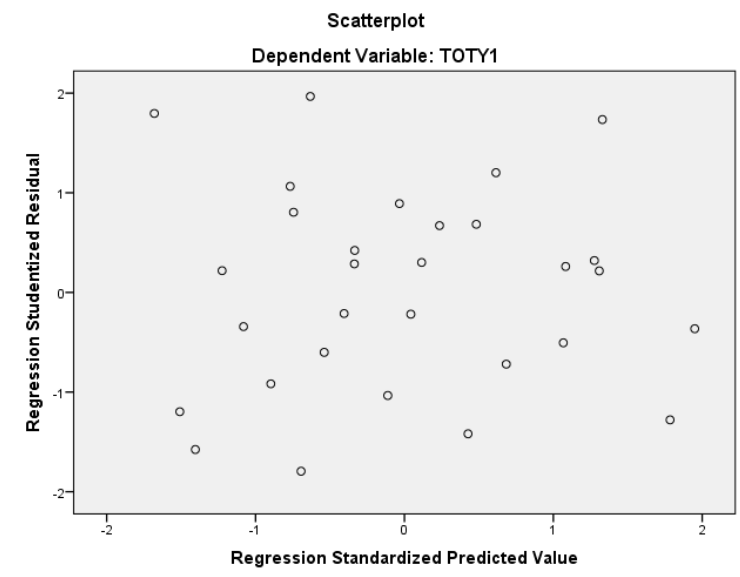

Figure 4 Heteroscedasticity Test Results

\section{Test Multicolonierity}

The results of multicollinearity test, the result of calculation of tolerance value shows that tolerance value $>0.10$ which means no correlation between independent variable more than $95 \%$, calculation of VIF value, from independent variable tested no VIF value more than 10 , it can be concluded that there is no multicolinearity between independent variables in the regression model. 
Table 2 Multicollonearity Test Results

\begin{tabular}{|l|r|r|}
\hline \multirow{2}{*}{ Model } & \multicolumn{2}{|c|}{ Collinearity Statistics } \\
\cline { 2 - 3 } & \multicolumn{2}{|c|}{ Tolerance } \\
\hline 1 (Constant) & .282 & \\
Fasilitas yang Tersedia & .385 & 3.540 \\
Keselamatan Lingkungan Kerja & .206 & 2.597 \\
Keterlibatan Karyawan & .598 & 4.856 \\
Kompensasi yang Seimbang & .354 & 1.674 \\
Komunikasi & .334 & 2.827 \\
Pengembangan Karir & .542 & 2.991 \\
Penyelesaian Masalah & .224 & 1.845 \\
Rasa Aman & .497 & 4.458 \\
Rasa Bangga terhadap Institusi & .258 & 2.010 \\
Restrukturisasi Pekerjaan & .642 & 3.871 \\
Lingkungan Kerja & & 1.557 \\
\hline
\end{tabular}

\section{Multiple Regression Analysis}

Based on Table 3. The data in the table above where the regression analysis results obtained the following equation:

Table 3 Multiple Regression Test Results

\begin{tabular}{|c|c|c|c|c|}
\hline \multicolumn{2}{|c|}{ Model } & \multicolumn{2}{|c|}{$\begin{array}{l}\text { Unstandardized } \\
\text { Coefficients }\end{array}$} & \multirow{2}{*}{$\begin{array}{l}\text { Standardized } \\
\text { Coefficients } \\
\text { Beta }\end{array}$} \\
\hline & & B & $\begin{array}{l}\text { Std. } \\
\text { Error }\end{array}$ & \\
\hline \multirow[t]{12}{*}{1} & (Constant) & .106 & 3.971 & \\
\hline & Fasilitas yang Tersedia (X1) & .335 & .119 & .260 \\
\hline & Keselamatan Lingkungan Kerja (X2) & .380 & .119 & .251 \\
\hline & Keterlibatan Karyawan (X3) & .395 & .180 & .237 \\
\hline & Kompensasi yang Seimbang $(\mathrm{X} 4)$ & .094 & .081 & .073 \\
\hline & Komunikasi (X5) & .362 & .152 & .196 \\
\hline & Pengembangan Karir (X6) & .034 & .137 & .021 \\
\hline & Penyelesaian Masalah $(X 7)$ & .013 & .143 & .006 \\
\hline & Rasa Aman (X8) & .400 & .156 & .264 \\
\hline & Rasa Bangga terhadap Institusi (X9) & .388 & .150 & .179 \\
\hline & Restrukturisasi Pekerjaan (X10) & .912 & .155 & .566 \\
\hline & Lingkungan Kerja (X11) & .024 & .069 & .021 \\
\hline
\end{tabular}

The above equation shows that if the independent variables are assumed to be fixed or zero, then the dependent variable of work motivation will go up by the constant value at the equation above that is 0,016 , it shows that there is an improvement on the employee's motivation of UPBJJ-UT Pangkalpinang either from the facility available, workplace safety, employee engagement, balanced compensation, communication, career development, problem solving, security, institutional pride, work restructuring and the work environment owned by UPBJJ-UT Pangkalpinang.

$\mathrm{Y}=0,106+0,335 \mathrm{X} 1+0,380 \mathrm{X} 2+0,395 \mathrm{X} 3+0,094 \mathrm{X} 4+0,362 \mathrm{X} 5+0,034 \mathrm{X} 6+$ $0,013 \times 7+0,400 \times 8+0,388 \times 9+0,912 \times 10+0,024 \times 11+e$

Figure 5 Linear Equations

Similarly, if there is an increase of $1 \%$ in the independent variable then the dependent variable of work motivation will have an increase of the coefficient value of each independent variable. 


\section{Partial Regression Coefficient Test (t test)}

Partially there are 7 (seven) variables that have positive and significant influence and 4 (four) variables that have positive but not significant influence. Variables that have positive and significant impacts are available facilities, workplace safety, employee engagement, communication, security, a sense of pride in institutions and work restructuring. While the variables that have positive but not significant influence are balanced compensation, career development, problem solving and work environment.

Table 4 Test Results $\mathrm{t}$

\begin{tabular}{|c|c|c|c|c|c|}
\hline \multirow[b]{2}{*}{ Model } & \multicolumn{2}{|c|}{$\begin{array}{c}\text { Unstandardized } \\
\text { Coefficients }\end{array}$} & \multirow{2}{*}{$\begin{array}{c}\begin{array}{c}\text { Standardized } \\
\text { Coefficients }\end{array} \\
\text { Beta }\end{array}$} & \multirow[b]{2}{*}{$t$} & \multirow[b]{2}{*}{ Sig. } \\
\hline & 8 & $\begin{array}{l}\text { Std. } \\
\text { Error }\end{array}$ & & & \\
\hline 1 (Constant) & .106 & 3.971 & & .027 & .979 \\
\hline Fasilitas yang Tersedia (X1) & .335 & .119 & .260 & 2.829 & .011 \\
\hline Keselamatan Lingkungan Kerja ( $\times 2$ ) & 380 & .119 & 251 & 3.193 & .005 \\
\hline Keterlibatan Karyawan (X3) & .395 & 180 & .237 & 2.197 & .041 \\
\hline Kompensasi yang Seimbang $\left(X_{4}\right)$ & .094 & .081 & .073 & 1.158 & .262 \\
\hline Komunikasi ( $\times 5)$ & .362 & .152 & .196 & 2.383 & .028 \\
\hline Pengembangan Karir $(\times 6)$ & .034 & .137 & .021 & 250 & .805 \\
\hline Penyelesaian Masalah $(X 7)$ & .013 & .143 & .006 & .092 & .928 \\
\hline Rasa Aman (X8) & .400 & .156 & .264 & 2.559 & .020 \\
\hline Rasa Bangga terhadap Institusi $(\times 9)$ & .388 & .150 & .179 & 2.588 & .019 \\
\hline Restrukturisasi Pekerjaan ( $\times 10)$ & .912 & .155 & .566 & 5.889 & .000 \\
\hline Lingkungan Kerja (X11) & .024 & .069 & .021 & .351 & .730 \\
\hline
\end{tabular}

Variables that have positive and significant impacts such as available facilities, workplace safety, employee engagement, communication, sense of security, institutional pride and work restructuring have a positive beta value, Thitung value greater than Ttable is 2.101 and significant value less than 0,05.

While the variables that have positive and insignificant effects such as balanced compensation, career development, problem solving and work environment have a positive beta value, but the value of T hitung is smaller than $\mathrm{T}$ table is 2.101 and significant value is greater than 0.05 .

\section{Simultaneous Regression Coefficient Test (F test)}

Based on data from Table 5. F calculation results, it can be seen that Fcount is 18.211 and Ftable with df $1=\mathrm{k}-1$ and df $2=\mathrm{n}-\mathrm{k}$, where $\mathrm{n}$ is the number of samples and $\mathrm{k}$ is the number of independent and dependent variables. Thus the Ftable value is 2.374 and the significance level is 0.05 . Means $F$ count $>F$ table is $18.211>2.374$ and the value $p=0,000<0.05$. Hence Ho is rejected and H12 accepted which means the available facility variables, workplace safety, employee involvement, balanced compensation, communication, career development, problem solving, security, institutional pride, work restructuring and work environment have a positive and significant influence simultaneous to work motivation. 
Table 5 Test Results F

\begin{tabular}{lrrrrr}
\multicolumn{5}{c}{ ANOVA $^{\mathrm{a}}$} \\
\hline Model & $\begin{array}{c}\text { Sum of } \\
\text { Squares }\end{array}$ & \multicolumn{1}{c}{ df } & Mean Square & \multicolumn{1}{c}{ F } & Sig. \\
\hline 1 Regression & 543.069 & 11 & 49.370 & 18.211 & $.000^{\circ}$ \\
& 48.797 & 18 & 2.711 & & \\
Residual & 591.867 & 29 & & & \\
$\quad$ Total & & & & \\
\hline a. DependentVariable:TOTY1 & & & \\
b. Predictors: (Constant), TOTX11, TOTX8, TOTX6, TOTX5, TOTX4, TOTX2, TOTX7, TOTX9, \\
TOTX1, TOTX3, TOTX10 \\
Sumber: data diolah
\end{tabular}

This means that the quality of work life variables simultaneously influence positively and significantly to work motivation of UPBJJ-UT Pangkalpinang employees. This is because the overall quality of work life variables have a high average value, especially on the variable pride of the institution. This means that any increase or decrease in Quality of Work Life together will give a significant influence on employee motivation in UPBJJ-UT Pangkalpinang.

\section{Multiple Determination Coefficient}

The coefficient of determination (R2) shows the number of Adjusted R Square of 0.867 or $86.7 \%$ which means variation of work motivation variables can be explained by available facility variables, work environment safety, employee involvement, balanced compensation, communication, career development, problem solving, security, institutional pride, work restructuring and work environment of $86.7 \%$, the remaining $13.3 \%$ is explained by other variables outside of the research variables.

Table 6 Coefficient Test Results Determination

Tabel 4.43 Model Summary

\begin{tabular}{l|c|r|r|r}
\multicolumn{5}{c}{ Model Summary $^{\mathrm{b}}$} \\
\hline Model & $\mathrm{R}$ & $\begin{array}{c}\mathrm{R} \\
\text { Square }\end{array}$ & Adjusted R Square & Std. Error of the Estimate \\
\hline 1 & $.958^{\mathrm{a}}$ & .918 & .867 & 1.646 \\
\hline a.Predictors: (Constant), TOTX11, TOTX8, TOTX6, TOTX5, TOTX4, TOTX2, TOTX7, \\
TOTX9, TOTX1, TOTX3, TOTX10 \\
b. Dependent Variable: TOTY1 \\
Sumber: data diolah
\end{tabular}

\section{DISCUSSION}

\section{Influence of Facilities Available to Work Motivation.}

Available facility variables are variables that partially affect the work motivation because the available facility variables according to the calculation results obtained $\mathrm{T}$ hitung of 2.829 larger than $\mathrm{T}$ tabel 2.101 and with significance of 0.011 is smaller than the level of significance of 0.05 . This means that partially available facilities variables positively and significantly influence employee work motivation UPBJJ-UT Pangkalpinang.

\section{Influence of Occupational Safety on Work Motivation}

Work environment safety variable is a variable that partially affect the work motivation due to work environment safety variables according to the calculation results obtained Thitung of 3.193 greater than Ttabel 2.101 and with significance of 0.005 smaller than the significance level of 0.05 . This means that the working environment safety variable partially positively and significantly affect the employee motivation of UPBJJ-UT Pangkalpinang.

\section{Influence Employee involvement on work motivation}


Employee involvement variable is a variable that partially influence to work motivation due to employee involvement variable according to calculation result obtained Thitung equal to 2,197 bigger than Ttabel 2,101 and with significance equal to 0,041 smaller than level of significance equal to 0,05 . This means that employee involvement variable partially positively and significantly influence to employee motivation UPBJJ-UT Pangkalpinang.

\section{Influence of balanced compensation on work motivation}

A balanced compensation variable is a variable that partially affect the work motivation due to balanced compensation variable according to the calculation results obtained Thitung of 1.158 smaller than Ttabel 2.101 and with significance of 0.262 greater than the significance level of 0.05 . This means that partially balanced compensation variables have a positive and insignificant effect on employee motivation of UPBJJ-UT Pangkalpinang. This is because the respondents stated that some statement items on the balanced compensation variable are still low, especially regarding UPBJJ-UT Pangkalpinang has given a reasonable incentive in accordance with the work I have done.

\section{Influence of Communication on Work Motivation}

Communication variable is a variable that partially affect the work motivation due to communication variables according to calculation results obtained Thitung of 2.383 greater than Ttabel 2.101 and with significance of 0.028 smaller than the significance level of 0.05 . This means that the partial communication variables positively and significantly affect the employee motivation UPBJJ-UT Pangkalpinang. This is because respondents stated that some statement items on the communication variable is high enough, especially about the leader always convey information quickly.

\section{Influence Career development on Work motivation}

The variable of career development is a variable that partially affect the work motivation due to career development variables according to the calculation results obtained Thitung of 0.250 smaller than Ttabel 2.101 and with significance of 0.805 greater than the significance level of 0.05 . This means that career development variables partially have a positive and insignificant effect on work motivation of UPBJJ-UT Pangkalpinang employees.

Influence Problem solving on work motivation

The problem solving variable is the variable that partially affect the work motivation because the problem solving variable according to the calculation results obtained Thitung of 0.092 smaller than Ttabel 2.101 and with significance of 0.928 greater than the significance level of 0.05 . This means that the problem solving variable partially positively and insignificantly affect the employee motivation of UPBJJ-UT Pangkalpinang.

\section{Influence of job security to work motivation}

Safety variable is a variable that has a partial effect on work motivation due to security variable according to the calculation result obtained by Thitung 2,559 is bigger than Ttabel 2,101 and with significance equal to 0,020 smaller than level of significance equal to 0,05 . This means that the partial security variable has a positive and significant effect on the employee's motivation of UPBJJ-UT Pangkalpinang.

\section{Influence of Proud of the Institution on Work Motivation}

Variable of pride to institution is a variable that partially influence to work motivation due to variable pride of institution according to calculation result obtained Thitung equal to 2,588 bigger than Ttabel 2,101 and with significance 
equal to 0,019 smaller than significance level equal to 0,05 . This means the variable pride of the institution partially positively and significantly influence the employee motivation UPBJJ-UT Pangkalpinang.

\section{Influence of Job Restructuring on Work Motivation}

Job restructuring variable is a variable that partially affect the work motivation due to work restructuring variables according to the calculation results obtained Thitung of 5.889 larger than Ttabel 2.101 and with significance of 0.000 smaller than the level of significance of 0.05 . This means that the partial restructuring variables positively and significantly affect the employee motivation of UPBJJ-UT Pangkalpinang.

\section{Influence Work environment to work motivation}

Work environment variable is a variable that partially affect the work motivation due to work development variables according to the calculation results obtained Thitung of 0.250 smaller than $\mathrm{T}$ tabel 2.101 and with significance of 0.805 greater than the significance level of 0.05 . This means that career development variables partially have a positive and insignificant effect on work motivation of UPBJJ-UT Pangkalpinang employees.

\section{Influence of Quality of Work Life on Work Motivation}

Variables incorporated in the quality of work life is a variable that affects simultaneously to work motivation due to the variable quality of work according to the calculation results obtained Thitung of 18.211 larger than Ttabel 2.374 and with significance of 0.000 smaller than the level of significance of 0.05 . This means that the quality of work life variables simultaneously influence positively and significantly to work motivation of UPBJJ-UT Pangkalpinang employees.

\section{CONCLUSION}

Based on the data and discussion of the research under the title "Analysis of the Effect of Quality Work of Life Factors on Employee Motivation UPBJJUT Pangkalpinang", it can be concluded that: (1) The overall variable has a high average value namely in the categories of 3.41-4.20 and variable pride of the institution has the highest average value of $4.21 \%$. Thus the majority of respondents feel proud of the institution while working at UPBJJ-UT Pangkalpinang. And in general, quality of work life factors that affect the work motivation is considered high (2) Partially there are seven variables that have positive and significant influence and four variables that have positive but not significant. Variables that have positive and significant impacts are available facilities, workplace safety, employee engagement, communication, security, institutional pride and work restructuring. While the variables that have positive but not significant are balanced compensation, career development, problem solving and work environment (3) Simultaneously the Quality of Work Life variable has a positive and significant influence on work motivation. This means that any increase or decrease in Quality of Work Life together will give a significant influence on employee motivation in UPBJJ-UT Pangkalpinang.

\section{References}

Abdullah, F. (2005). HEdPERF versus SERVPERF: The quest for ideal measuring instrument of service quality in higher education sector. Quality Assurance in Education, 13 (4), 305-328. 
Cascio, W. F. (2003). Managing Human Resources. Colorado: Mc Grawa Hill.

Clemes, M. D. et. al. (2013). Mobile communications: a comprehensive hierarchical modelling approach. Asia Pacific Journal of Marketing and Logistics, 26 (1), 114-146.

Dessler. (2006). Manajemen Sumber daya manusia. Jakarta: Indeks

Flippo, E. B. (2005). Manajemen Personalia Edisi Keenam. Jakarta: Raja Grafindo.

Ghozali, I. (2009). Aplikasi Analisis Multivariate Dengan Program SPSS. Ed. 4. Semarang: Badan Penerbit Universitas Diponegoro

Gibson, J. L. (2009). Organization: Behavior, Structure, Processes. NewYork: McGraw-Hill Companies.

Haryono, Y. (2011). Hubungan Komponen Kualitas Kehidupan Kerja (Quality of Work Life) dengan Motivasi Kerja Perawat Pelaksana dan Bidan di Rumah Sakit Hermina Depok Tahun 2011. URL:http://repository.uinjkt.ac.id/dspace/bitstream/123456789/28902/1/ ANIS\%20SAPUTRI-FKIK.pdf. [accessed 18 Februari 2016]

Hasibuan, P. M. (2007). Manajemen Sumber Daya Manusia. Jakarta: PT Binarupa Bumi Aksara.

Ilyas, Y. (2004). Perencanaan SDM Rumah Sakit : Teori, Metode dan Formula. Fakultas Kesehatan Mayarakat. Depok: Universitas Indonesia Press.

Mangkuprawira, S. (2003). Manajemen Sumber Daya Manusia Strategik. Jakarta: PT. Ghalia Indonesia.

Martoyo, S. (2007). Manajemen Sumber Daya Manusia, Edisi 5. Cetakan Pertama. Yogyakarta: BPFE.

Nawawi, H. (2001). Manajemen Sumber Daya Manusia Untuk Bisnis dan Kompetitif. Yogyakarta: Gajah Mada University Press.

Notoatmodjo, S. (2009). Pengembangan Sumber Daya Manusia. Jakarta: Rineka Cipta.

Purwaningdiyah, et al. (2010). Borang UPBJJ-UT dalam rangka Akreditasi Program Studi Universitas Terbuka. Padang. UPBJJ-UT Padang Press.

Riduwan. (2007). Skala Pengukuran Variabel-variabel Penelitian. Bandung: Alfabeta.

Rivai, H. V., \& Sagala, E. J. (2009). Manajemen Sumber Daya Manusia untuk Perusahaan Dari Teori ke Praktik. Jakarta: Rajawali Press. 
Samtica, S. (2011). Hubungan Komponen Kualitas Kehidupan Kerja (Qualiy of Work Life) Dengan Motivasi Kerja Perawat Pelaksana di RS Haji Jakarta Tahun 2011. URL:http://lib.ui.ac.id/file?file=digital/20297144-SSinta\%20 Samtica.pdf. [access 25 Februari 2016]

Santoso, H. (2014). Pengaruh Layanan Akademik Terhadap Kepuasan Mahasiswa Program Pascasarjana Universitas Terbuka Pada Unit Program Belajar Jarak Jauh (UPBJJ) Mataram. Jurnal Pendidikan Terbuka dan Jarak_Jauh, 15 (2), 88-98

Sekaran, U. (2011). Research Methods For Business. Ed.4. John Wiley: Amerika Serikat.

Sugiyono. (2004). Metode Penelitian Administrasi. Ed.5. Alfabeta: Bandung.

Siagian, S. P. (2012). Manajemen Sumber Daya Manusia. Jakarta: Bumi Aksara.

Sumijatun. (2009). Manajemen Keperawatan: konsep Dasar dan Aplikasi Pengambilan Keputusan Klinis. Jakarta: CV. Trans Info Media.

Umar, H. (2002). Riset Sumber Daya Manusia. Jakarta: PT Gramedia Pustaka Utama.

Winardi, J. (2002). Motivasi dan pemotivasian dalam Manajemen. Jakarta: Raja Grafindo Persada

Werther, W. B., \& Davis, K. (2003). Human Resource and Personnel Management. Fifth Edition. New York: McGraw-Hill, Inc. 